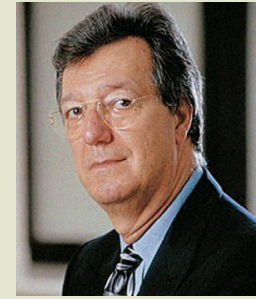

Carlos Osmar Bertero

FGV-EAESP carlos.bertero@fgv.br

\title{
Tempo e progresso
}

\section{TALVEZ A PRINCIPAL EXPORTAÇÃO DA CULTURA OCIDENTAL PARA O RESTO DO MUNDO NÃO SEJA NEM UM PRODUTO OU UM SERVIÇO, MAS UM VALOR OU UMA IDÉIA: O PROGRESSO.}

Para nós essa idéia está tão presente e incorporada ao nosso ideário que não nos damos conta de sua recente criação e de que ainda inexiste em muitas culturas. Noutras simplesmente não existiu antes que fossem tocadas e influenciadas pela cultura do Ocidente.

O progresso implica um movimento, ao longo do tempo, em que as coisas melhoram. A idéia é de ascensão, de subida, como se as boas coisas estivessem sempre acima e nunca abaixo. Como administradores, essa crença no progresso como ascensão nos impregna profundamente.

Por exemplo, acreditamos que nossas empresas podem ser melhoradas. Cremos ser possível desenvolver talentos em pessoas mediante programas de treinamento, de sistemas de motivação e da criação de um clima organizacional adequado. Enquanto administradores, não somos fatalistas, mas voluntaristas, quer dizer, partimos do princípio de que somos senhores de nossa vida e destino e, por consequêencia, também das empresas que dirigimos. Não estamos fadados à estagnação ou a um desempenho medíocre, mas sempre somos capazes de melhorar ou progredir.

O progresso também permeia a gestão estratégica dos negócios. Dizemos que temos que rever criticamente, e com frequuência, a estratégia de nossa empresa; mesmo que estejamos sendo bem-sucedidos, a repetição poderia nos conduzir ao declínio. É necessário rever sempre, pois o sucesso de hoje pode ser a raiz da ruína amanhã. A razão para essas crenças é nossa forma de representar o tempo.

Tempo e progresso estão intimamente associados em nossa cultura. Na verdade, o segundo só é possível com o primeiro: o progresso só acontece se o tempo for linear e finito. É mais difícil falar em progresso quando o tempo é circular e infinito - tal como ocorre na maioria das culturas diferentes da nossa. Há poucas evidências históricas de que outros povos, em outras épocas, tenham tido fascínio por mudar ou acreditado que, se não mudassem, as coisas viriam abaixo, abrindo espaço para o fracasso. O tempo finito condiciona o estabelecimento de limites para a realização das tarefas e para a duração de tudo. Cria, conseqüentemente, o pano de fundo para o estresse, pois não haveria estresse sem prazos, pressa, objetivos e metas a serem atingidos, e sem a idéia de progresso.

Obviamente não podemos negar a idéia de progresso e seu valor, responsável em grande medida pelas mudanças que ocorreram no planeta ao longo dos últimos séculos. Mas é sempre conveniente, sobretudo nesta era de multiculturalismo, lembrar que nem tudo é esculpido em rocha, como o tempo linear e finito, e o progresso. Essas são coisas inventadas por nós próprios. Somos de fato senhores de nossa vida e destino, às vezes criando paraísos de felicidade e realizações, outras, construindo poços de sofrimento. $\boldsymbol{x}$ 